\title{
An ethno-linguistic dimension in transnational activity space measured with mobile phone data
}

Veronika Mooses (1) ${ }^{1 凶}$, Siiri Silm (10 ${ }^{1}$, Tiit Tammaru (1) ${ }^{1} \&$ Erki Saluveer (1) ${ }^{2}$

In addition to permanent migration, different forms of cross-border mobility were on the rise before the COVID-19 pandemic, ranging from tourism to job-related commuting. In this paper ethno-linguistic differences in cross-border mobility using the activity space framework are considered. New segregation theories emphasise that segregation in one part of the activity space (e.g. in residential neighbourhood) affects the segregation in other parts of the activity space (e.g. in workplace), and that spatial mobility between activity locations is equally important in the production and reproduction of ethnic inequalities. Until now, segregation in activity spaces has been studied by focusing on daily activities inside one country. In reality, an increasing number of people pursue their activities across different countries, so that their activity spaces extend beyond state borders, which can have important implications for the functioning of ethno-linguistic communities and the transfer of inequalities from one country to another. This study takes advantage of mobility data based on mobile phone use, and the new avenues provided for the study of ethno-linguistic differences in temporary cross-border mobility. Such data allow the study of different cross-border visitor groups-tourists, commuters, transnationals, long-term stayers-by providing the means to measure the frequency of visits and time spent abroad, and to link together the travel of each person over several years. Results show that members of the ethno-linguistic minority population in Estonia make more trips than members of the ethno-linguistic majority, and they also have higher probability of being tourists and cross-border commuters than the majority population, paying frequent visits to their ancestral homelands. The connections between ethno-linguistic background and temporary cross-border mobility outlined in this study allows for future discussion on how (in)equalities can emerge in transnational activity space and what implications it has for segregation.

\footnotetext{
${ }^{1}$ Department of Geography, Institute of Ecology and Earth Sciences, Faculty of Science and Technology, University of Tartu, Tartu, Estonia. ${ }^{2}$ Positium,

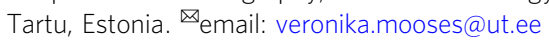




\section{Introduction}

teadily growing figures of international migrants (International Organization for Migration, 2019), tourists (UNWTO, 2020), and cross-border commuters prior to the COVID-19 pandemic indicated that more and more people were frequently on the move, placing mobility at the heart of the functioning of contemporary societies (Cresswell, 2011). The mobilities paradigm stresses the need to discard spatial fixity and boundedness in social studies and instead focus on how new meanings, sociality and identity are created through the movement of people, ideas, information, and goods (Cresswell, 2011). The mobility justice concept elaborates it further by intersecting 'mobile ontology' with the social justice framework (Sheller, 2019; Cook and Butz, 2019). This concept provides a theoretical tool to analyse the interlinkages between different types and forms of mobilities and power, and the resulting spatial inequalities between different ethnic groups.

The concept of activity space allows research on segregation and mobility to be integrated into a single analytical framework. New theories such as the segregation cycle (Krysan and Crowder, 2017) and the vicious circle of segregation (van Ham et al., 2018) emphasise that segregation in different activity sites (neighbourhood, work, school, leisure) is related (see also Kwan, 2013; Wong and Shaw, 2011; van Ham and Tammaru, 2016). Spatial mobility is, on one hand, a key mechanism for connecting activity sites, and creating exposure to opportunity structures, people, neighbourhoods, countries and cultures (Krysan and Crowder, 2017; Cook and Butz, 2019). For example cross-border mobility for a better job and higher salary allows one to invest into housing in one's homeland (Anniste and Tammaru, 2014), hence to help reduce housing inequalities and residential segregation. On the other hand, through mobility, inequalities can be produced and reproduced. For example, developing a cardependent urban environment favours those who have access to personal cars and neglects the access to opportunity structures for the less well-off. Access to mobility is seen as a prerequisite to freedom and progress, but it is often shaped by institutional and structural factors (Benz, 2019; Cass and Manderscheid, 2019).

What is more, even though the 'mobilities paradigm' and the concepts of 'mobility justice' and 'activity space' are all critical towards the sedentarist viewpoint on social processes (Sheller and Urry, 2006; Cook and Butz, 2019), ethnic segregation is still mostly studied within a single country, and often as in relation to residential neighbourhoods and permanent migration (Cachia and Jariego, 2018). This remains blind to the mobile and interconnected world of today where different activity sites may be located in different countries. The sedentarist view on ethnic segregation therefore neither corresponds to today's mobile world nor to the true extent of people's activity spaces. This calls for the need to extend the single-country view on segregation to a multicountry view that, in turn, brings spatial mobility to the heart of understanding how ethnic inequalities are produced and reproduced in a contemporary world.

The overarching aim of this study is, firstly, to extend the single-country approach to understanding segregation to an analysis of transnational activity space and, secondly, to ascertain whether there are differences in transnational activity space between ethno-linguistic population groups. Most importantly, we are interested in what are the differences in cross-border mobility-being tourists, commuters, transnationals, long-term stayers-between ethno-linguistic groups. For this we need novel data. The present study makes use of mobile phone data that helps to shed light to the following research questions:

1. What are the ethno-linguistic differences in cross-border mobility as related to the number and average duration of cross-border trips, number of days spent abroad, and number of countries visited?

2. What are the ethno-linguistic differences that can be seen in the members of different visitor groups (tourists, commuters, transnationals, long-term stayers), as well as the ethnolinguistic differences in destination countries?

We draw our data from Estonia. Estonia is useful for studying ethnic differences in cross-border mobility for several reasons. First, it is a country that is deeply divided across ethno-linguistic lines, with Estonian majority and Russian-speaking minority groups being highly segregated in in places of residence (Leetmaa, 2017), schools (Põder et al., 2017), the labour market (Saar and Helemäe, 2017), and during periods of free time (Kukk et al., 2019; Silm et al., 2018). Because activity sites are segregated, mobility between them can differ as well. Previous research shows that permanent migration patterns differ along ethno-linguistic lines (Anniste and Tammaru, 2014), but there are no studies of ethnic differences in temporary cross-border mobility in Estonia. Secondly, Estonia provides unique mobile phone data that allows for an in-depth study of various forms of cross-border mobility and can show how this differs between ethno-linguistic groups. Previous studies in the field are either qualitative or focus on one type of cross-border mobility such as tourism. The main advantage of mobile phone data is that we are able to study all these types of cross-border mobility by observing the trips of individual people over several years.

\section{Theoretical background}

Activity space-based segregation. The human activity space has traditionally been defined as a set of routine activities and mobility between important activity locations (Golledge and Stimson, 1997) and this concept has been frequently applied in segregation studies (i.e. Wong and Shaw, 2011; Järv et al., 2015). Alongside with the emergence of new approaches to segregation studies, advances in tracking technologies and big data analytics have enabled the measurement of ethnic differences in different activity sites or in the whole activity space simultaneously (e.g. Järv et al., 2015; Shen, 2019; Silm et al., 2018; Toomet et al., 2015; $\mathrm{Xu}$ et al., 2019) that often cannot be captured with traditional data collection methods. Thus, a switch from a single-site to a multi-site understanding of ethnic segregation has taken place, in which people can experience segregation in various activity sites (Wong and Shaw, 2011). In addition to residential segregation, other sites of human activity such as schools, workplaces, and leisure need to be taken into account to understand adequately ethnic segregation and integration (Wang et al., 2012; Silm et al., 2018). Multi-site studies from various national contexts conclude that segregation tends to be the highest in people's places of residence, lower in workplaces, and diverse during leisure activities depending on the type of activity (Hall et al., 2019; Strömgren et al., 2014; Toomet et al., 2015; Silm et al., 2018). Ethnic differences relate to the full activity space, too. For example, studies in Estonia have found that the extent of activity space of members of the Russian-speaking minority tends to be smaller than that of the members of the Estonian majority population (Silm et al., 2018; Järv et al., 2020).

In addition to understanding segregation in various activities, it is important to understand how inequalities from one activity site transmit into another and thereby form the vicious circles of segregation. This reproduction of spatial inequality between members of different ethnic and social groups may emerge because of many factors, such as policies, economic resources, social networks, discrimination, and the lived experiences of people that often operate in overlapping ways (Krysan and 
Crowder, 2017; van Ham et al., 2018). Socio-economic stratification due to lower income or discrimination can lead to reduced opportunities in the labour and housing markets (Allen and Turner, 2012), as well as inaccessibility to mobility and services. Studies conducted in Hong Kong have shown that people on low incomes living in disadvantaged neighbourhoods tend to undertake other everyday activities in other underprivileged neighbourhoods (Yip et al., 2016) and are therefore more likely to be exposed to people of similar socio-economic backgrounds (Wang and $\mathrm{Li}, 2016$ ). Such exposure to neighbourhoods and people shapes the knowledge base of the urban areas (opportunities, housing, perceived neighbourhood atmosphere, etc.) that in turn affects the choice set for where to live, work or spend one's free time (Krysan and Crowder, 2017; van Ham and Tammaru, 2016). Differences in the activity sites can also be a result of selective differences and preferences related to cultural values, norms, and customs (Floyd, 1999). This can be evident, for example, in group-specific leisure-time choices (Kukk et al., 2019) and in activity locations during public and national holidays (Mooses et al., 2016).

Segregation in different activity sites and mobility between those activity sites is closely related to social networks, through which important information flows. Social networks as a medium for information have changed as a result of the growth of social media and digital connection, and are more likely to transcend country borders than at any time before. The influence of social networks and exposure to similar people can, on one hand, (re) produce segregation, and on the other hand, help migrants to adapt to the host society (van Kempen and Özüekren, 1998; Ahas et al., 2017). Social networks help to mitigate cultural shock upon arrival to a new country, for example by providing information on jobs and places where to live (Patacchini and Zenou, 2012; Xu et al., 2019), which often slows down integration in the host society (Zorlu and Mulder, 2010). However, according to the most recent studies, both inter- and intra-ethnic ties are actually important in the integration process of the minority group (Vacca et al., 2018; Verdier and Zenou, 2017).

A related important (and often overlooked) aspect of activity space-based segregation relates also to spatial mobility between activity sites. This is an important shortcoming since, in today's mobile society, good connectivity often matters more than physical proximity (Wissink et al., 2016). The ability to be mobile has become 'a prerequisite' for progress, freedom, and a route for exiting from a marginal position in the society (Cass and Manderscheid, 2019; Benz, 2019). Spatial mobility enables people to be exposed to others in social encounters and physical environments that are different from usual, but it is also closely linked to social exclusion in terms of accessibility to different modes of transport and infrastructure (Järv et al., 2015; Wang et al., 2012). Thus, not being able to be mobile, for example, being unable to work abroad, can reinforce exclusion from groups dissimilar to us, and "deepen prejudices and withdrawal from 'others”' (Wissink et al., 2016, p. 127). Mobility justice framework takes this critical point further by moving beyond the notion of accessibility by claiming that, through (im)mobility, different (in) equalities can be realised and transmitted in space. Sheller (2019) aptly notes that a more holistic view on mobilities and resulting socio-spatial inequalities is necessary. A constant increase in the mobility capital of people can result in the displacement of inequalities from one country to another (Sheller, 2019), calling for the need for a transnational viewpoint.

Transnational activities and cross-border mobility. Transnational activities refer to human activities that take place beyond nation-state borders and link people to different social, economic, and political cross-border networks (Deutschmann, 2016). Such activities include both physical crossing of national borders and cross-border communications that take place in digital space (Delhey et al., 2015; Deutschmann, 2016). Physical cross-border mobility could be related to living abroad and visiting family members and friends or to spending holidays back in one's country of origin (Waldinger, 2008; Delhey et al., 2015), working or studying abroad for a certain period of time (Delhey et al., 2015), having a second home or holiday home(s) abroad (Delhey et al., 2015; Hannonen et al., 2015), etc. In addition to more or less regular transnational activities and cross-border mobility that tends to be related to a relatively small proportion of the population, tourism is another form of irregular cross-border mobility that involved rapidly growing numbers of people (Saluveer et al., 2020) before the start of COVID-19 pandemic.

Social links between people can trigger travel and activities abroad (Sheller and Urry, 2006) and enhance mobility capital (Benz, 2019). According to Waldinger (2008), the most frequent transnational activity relates to migrants' travel to their country of origin to visit family members and friends. Although physical travel is a geographical phenomenon that is strongly related to distance, the impact of distance has largely been neglected in the conceptualisation of transnationalism (O'Connor, 2010). The relationship between distance and the propensity to perform transnational activities is not linear. While Deutschmann (2016) states that most transnational activities occur over relatively short distances (people are more likely to form transnational ties with others in neighbouring countries or in the same geographical regions), case studies on certain ethno-linguistic groups and postcolonial settings identify strong transnational ties also over long distances (e.g. O'Connor, 2010). Travel to one's country of origin is seen to play an important role in sustaining ethnic identity and language, refreshing social ties and social capital, maintaining or discovering one's roots (Duval, 2003; Li and McKercher, 2016; Verdery et al., 2018; Hung et al., 2013), adapting to cultural changes in the host society (Ehrkamp, 2005) or, conversely, helping to form new (transnational) ethnic identities (Bolognani, 2014). Because of localised knowledge and networks, ethnic minorities may pursue business in their country of origin that contributes to the increase of cross-border business trips (Seetaram, 2012). As a consequence, the lines between migrants and different types of visitors (tourists, commuters, etc.) as well as between different types of cross-border mobility may become blurred (Humbracht, 2015).

It has been argued that longing for the "homeland" and related return visits restrict visits to other destinations and this is especially the case for first-generation migrants (Ali and Holden, 2006). However, the transnational functioning of ethnic communities may transcend several generations (Griffin, 2017), mostly when people search for their "roots" by visiting their ancestral homeland as tourists rather than for meeting relatives and friends (Huang et al., 2016). Successors can also "inherit" or take-up their ancestors' travel patterns, resulting in so-called "learned behaviour" (Klemm, 2002; McKercher and Yankholmes, 2018) or use social links to enhance mobility capital (Benz, 2019).

The wish to maintain one's and one's children's ethnolinguistic identity may thus play an important role in crossborder mobility alongside other socio-demographic variables, such as gender, income, and age (Hughes and Allen, 2010; Williams and Chacko, 2008). This may be an import trigger of cross-border mobility for people who have changed their country of residence. Previous research on ethno-linguistic differences in cross-border mobility have mainly applied a qualitative research design or are based on relatively small samples when quantitative methods have been used, covering topics such as the meaning of return visits to different ethno-linguistic groups (Bolognani, 2014; 
Hung et al., 2013; Ali and Holden, 2006), preferences for choice of destination (Hughes and Allen, 2010), number of holidays taken (Klemm, 2002), or number of foreign trips (Feng and Page, 2000). For example, a study in New Zealand shows that the Chinese in New Zealand travel abroad more often than members of the majority population (Feng and Page, 2000). They mainly go abroad to visit relatives back in their homeland, followed by business and holiday trips that often involve going to their homeland as well (Feng and Page, 2000). Case studies from the UK have shown that citizens with Asian or Irish origin go abroad equally often when compared with the members of the majority population, and the differences in destinations stem mainly from preferences (Klemm, 2002) or from the "pull"-effect of country of origin (Hughes and Allen, 2010). Hughes and Allen (2010) further noted that the frequency of visits decreases with age and across migrant generations, but the emotional tie as a factor shaping cross-border mobility is still evident in destination choices.

To conclude, a complex web of cross-border mobilities has emerged as a result of people starting to travel abroad due to changing their country of residence, work location or other reasons, along with trips back to the former homeland. However, less is known about how transnational activities and cross-border mobility varies between ethno-linguistic groups, and how it relates to (in)equality and segregation processes in countries of origin and destination. For example, cross-border commuters who work and live in segregated communities abroad may use their income to exit from poverty and segregation in their homeland. Research of Estonians living in Finland has shown that many envision only a temporary stay and, therefore, do not invest in housing in Finland but rather use their income to improve their housing conditions back in Estonia (Anniste and Tammaru, 2014). Thus, the motivation and patterns of cross-border mobility may vary between ethnio-linguistic and social groups in an important and meaningful way.

Study context: Estonia. Estonia is a small country in Northern Europe with 1.3 million inhabitants. According to the Census of 2011, the major ethno-linguistic group, Estonians, comprise 69\% of the population and the largest ethnic minority group, Russians, make up 25\% (Statistics Estonia, 2011). The ethnic minority population of Estonia was mainly formed during the Soviet occupation (1944-1991), when different ethnic groups (Russians, Ukrainians, Byelorussians, and others) were brought to Estonia for several reasons. The dominant language of communication in the Soviet Union was Russian, thus, many other nationalities apart from Russians from former Soviet republics living in Estonia speak the Russian language either as a mother tongue or as a communication language in everyday settings. Hence, there are two major ethno-linguistic groups in the country, Estonians and Russian-speaking minority groups (Vihalemm, 1999). Language does not only serve an instrumental function for communication, but it has also a symbolic value for distinguishing one social group from the 'other'. After Estonia regained independence in 1991, the instrumental function of the Russian language dropped significantly compared with the Soviet era on the one hand, but it gained symbolic importance in the formation of a new group identity for minority populations on the other (Vihalemm, 1999). The ability to speak Russian or the choice to use it every day has become the dominant feature for a common group identity-the Russian-speaking minority (Mägi et al., 2020).

Different activity sites in Estonia are also ethno-linguistically divided. The roots of segregation date back to the Soviet era labour market and immigrant residential placement policies, and

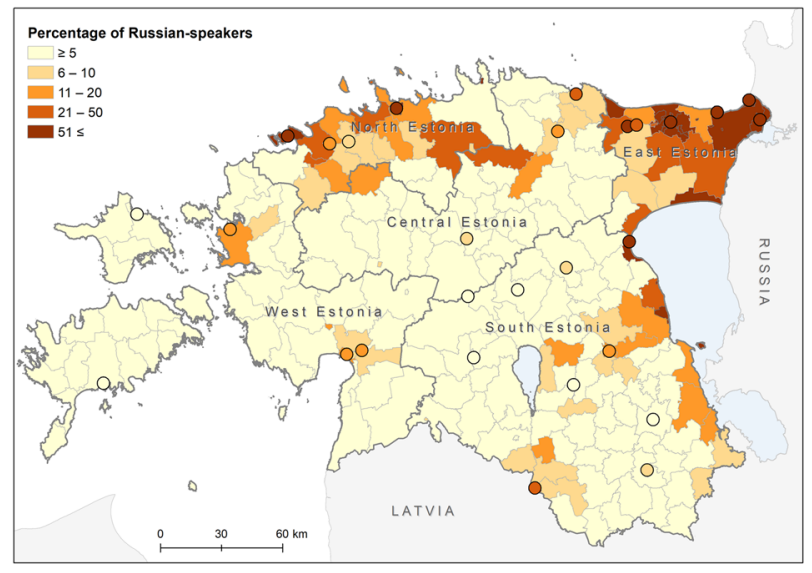

Fig. 1 Distribution of Russian-speaking population in Estonia. Data sources: Statistics Estonia (2011), Estonian Land Board (2011).

segregation has grown further over the last 30 years (Mägi et al., 2020). As a reaction to Russification during Soviet times, the nationalisation policies in a re-independent Estonia aimed at restoring the importance of Estonian language and Estonian citizenship (Brubaker, 2011). The socio-economic positions of the two ethno-linguistic groups differ substantially. Estonians tend to work in white-collar occupations and Russian-speakers in bluecollar occupations (Tammaru and Kulu, 2003; Saar and Helemäe, 2017). Because of modest levels of mixed-ethnic families (van Ham and Tammaru, 2011), individual differences in pay are amplified at the household level. Because money buys choice in the housing market, ethnic residential segregation which is measured with the index of dissimilarity (Silm et al., 2018) and co-presence (Toomet et al., 2015) is even higher than ethnic workplace segregation. Preferences may also matter, because those Russian-speakers who change their place of residence tend to settle in places with high shares of Russians both at the national level as well as within cities (Mägi et al., 2016). Russian speakers are geographically concentrated in North and East Estonia and in the larger cities (Fig. 1). In many of the cities of East Estonia, Russian speakers form a majority population. In the capital city of Tallinn in North Estonia, Estonians and Russian speakers are almost equal in number. In all other parts of Estonia, Estonians are in the majority. Hence, Estonia again provides an interesting context because the national-level ethno-linguistic minority group (Russian-speakers) are themselves a majority in certain parts of the country.

Joint leisure time activities are sometimes seen as a way to promote inter-ethnic communication, contacts, and integration (Peters and de Haan, 2011). Even though leisure time segregation tends to be lowest compared with other parts of the activity space (Silm et al., 2018), studies have shown a lack of interaction between Estonians and Russian-speakers in certain types of leisure activities (Kukk et al., 2019). In fact, according to Korts (2009), most of the interethnic contacts between Estonians and Russian-speakers occur in the public sphere (at work, on the street, on public transport). Personal and family networks tend to be segregated. One of the root causes for this is the linguistically separated school system in Estonia (the existence of different Estonian-language and Russian-language schools), which does not encourage the formation of social networks and contacts beyond ethnic lines (Korts, 2009).

Less is known about the ethno-linguistic differences in various forms of temporary cross-border spatial mobility, including tourism, visiting family members and friends, and work. One of the most important of the structural factors that affect 
cross-border mobility is citizenship and accompanying visa requirements. The three biggest groups of citizenship in the Estonian population are those with Estonian citizenship (85\%), which amongst other rights allows visa-free travel, work, and study in European countries, but a visa for travelling to Russia is required; Russian citizenship (7\%), which allows visa-free travel between Estonia and Russia; and an Alien's passport (6\%), which allows visa-free travel in European countries as well as to Russia (Statistics Estonia, 2016).

A new transnational field for cross-border mobility was opened for Estonia in 2004, when the country joined the European Union. Finland became one of the most important destination countries, and it now hosts the largest Estonian overseas community in the world (Anniste and Tammaru, 2014). This is due to the geographical and cultural proximity between Estonia and Finland, and the higher living standards and salaries in Finland. Hence, Estonia has strong new transnational ties with Finland, but it also has important transnational ties with Russia that is the ancestral land for ethnic Russians living in Estonia.

\section{Data and methods}

Mobile phone data. This study used passive mobile positioning data from an Estonian mobile network operator (MNO). Passive mobile positioning data include location information of mobile phones based on call activities (Call Detail Records, i.e., CDRs) stored automatically by the MNO (Silm et al., 2020). Call activity data consist of data records of mobile phone usage (incoming and outgoing calls and outgoing messages) in the cellular network. Approximately $94 \%$ of the Estonian population have access to mobile phones (Eurobarometer, 2014). Mobile phone network coverage is $99 \%$ and signal strength in Estonia is generally very good (Estonian Consumer Protection and Technical Regulatory Authority, 2019). There is a growing body of research based on CDR data that has focused on human mobility inside one country: measuring human mobility and the extent of activity space (Järv et al., 2014; Kamenjuk et al., 2017), internal migration (Lai et al., 2019), spatial segregation (Silm and Ahas, 2014; Silm et al., 2018; Mooses et al., 2016; Xu et al., 2019), and inbound tourism (Raun et al., 2016). Roaming data enables analysis of cross-border mobility with a more precise temporal resolution and the ability to distinguish visitor groups (including one-day visitors, commuters, etc.), including those not captured in official tourism statistics (Saluveer et al., 2020). Outbound roaming data has been applied to study cross-border mobility, for example in Estonia (Masso et al., 2019; Silm et al., 2020) or in the mobility of Syrian refugees (Kılıç et al., 2019).

CDR data consist of the time, location, and a randomly generated unique pseudonymous ID code for the SIM card, which is generated by the MNO (Saluveer et al., 2020). We consider every pseudonymous SIM card ID as a mobile phone user. Researchers cannot associate the data with specific people or phone numbers, thus ensuring anonymity to the researcher. This study uses two types of passive mobile positioning data for the period 2014-2016.

1. Outbound roaming data-call activities of mobile phone users made whilst abroad with SIM cards registered to Estonian MNOs. The location information is given to the accuracy of the country: ISO alpha 2 codes represent the country where the call activity has been made. Outbound roaming data from MNO was processed by cleaning and calculating additional variables using a methodology introduced by Saluveer et al. (2020).

2. Domestic data-CDRs of mobile phone users with SIM cards registered to Estonian MNOs whilst in Estonia. Domestic data from MNO was processed using the anchor point model introduced by Ahas et al. (2010). Based on the location and frequency of call activities, the anchor point model applies eight steps to detect personal meaningful locations such as place of residence, location of employment, and secondary locations, which are called as anchor points in the model. The time step for calculating the anchor points is one month. The network cells that are visited regularly and have the highest number of days in terms of call activities are considered to be residential or work-related anchor points which are, in turn, differentiated based on the timing of call activities (see Ahas et al., 2010).

Based on outbound roaming and domestic data, trips and visits were generated based on countries visited, time of call activities, and the distribution of time between consecutive call activities (Saluveer et al., 2020). The trips start and end in Estonia and one trip can consist of several visits to different countries. For each trip, the following variables were calculated: trip ID, visit ID, start, and end time of the visit. The length of stay abroad depends on when the person performs the first and last call activity outside Estonian territory.

By using the anchor point model (Ahas et al., 2010), residential location (home anchor point) for every month was calculated for each phone user. The analysis includes a single place of residence, which is the county with the highest number of month-based anchor points. In the analysis, Estonian counties are grouped according to five NUTS III (Statistics Estonia, 2015) categories (Fig. 1).

Some personal characteristics of mobile phone users are also available. By signing a contract with a mobile operator, a person can provide information about their gender, year of birth, and preferred language of communication (Estonian, Russian, or English). Since language is an important aspect of ethnic and cultural identity in Estonia (Vihalemm, 1999; Mägi et al., 2020), the preferred language of communication is used as a proxy for ethno-linguistic background in this study: Estonian for Estonianspeakers and Russian for Russian-speakers. Since the focus of the study is on Estonian-speakers and Russian-speakers and English is a preferred language for only a fraction of people, we exclude them from our study. All three datasets (outbound roaming, domestic, and personal characteristics data) can be linked through the pseudonymous ID code of a phone user.

The study includes people (hereinafter named as "visitors") who made at least one trip abroad and provided their personal characteristics (preferred communication language is Estonian or Russian, gender, year of birth) to the MNO and for whom place of residence can be identified. The number of people meeting these criteria was 75,118 , and these form our research population (Table 1).

The collection, storage, and processing of data is in accordance with the EU requirements on the protection of personal data as per EU directives on handling personal data and the protection of privacy in the electronic communications sector through the General Data Protection Regulations (European Parliament and Council of the European Union, 2016).

Analytical framework. This study is based on an activity-space segregation approach. The concept of activity space has traditionally been applied to study activities and spatial mobility in one country. Due to the fact that many activities such as working, studying, shopping, and leisure are increasingly being conducted abroad, cross-border mobility increases too. Thus, both activity sites and mobility have cross-border dimensions that must be included in the activity space concept to fully take into account human spatial behaviour. For this reason, we introduce a new term "transnational activity space" to cover cross-border 


\section{Table 1 Distribution of people in categories for analysis.}

\begin{tabular}{lrr} 
Variable & Number of people & Percentage \\
\hline Language & & \\
$\quad$ Russian & 11,366 & 15 \\
$\quad$ Estonian & & 85 \\
Gender & 63,753 & \\
$\quad$ Female & 42,996 & 57 \\
$\quad$ Male & 32,122 & 43 \\
Year of birth (age) & & \\
1917-1956 (59-98) & 14,074 & 19 \\
1957-1966 (49-58) & 20,722 & 28 \\
1967-1976 (39-48) & 25,395 & 34 \\
1977-1986 (29-38) & 13,138 & 17 \\
$\quad 1987-1996(19-28)^{a}$ & 1789 & 2 \\
Place of residence & & 41 \\
$\quad$ North Estonia & 30,498 & 12 \\
$\quad$ West Estonia & 9192 & 10 \\
$\quad$ Central Estonia & 7654 & 29 \\
$\quad$ South Estonia & 21,904 & 8 \\
$\quad$ East Estonia & 5870 & 100 \\
Total & 75,118 & \\
\hline aReference categories in regression analysis. & \\
bAge in parenthesis is calculated in 2015. & & \\
\hline
\end{tabular}

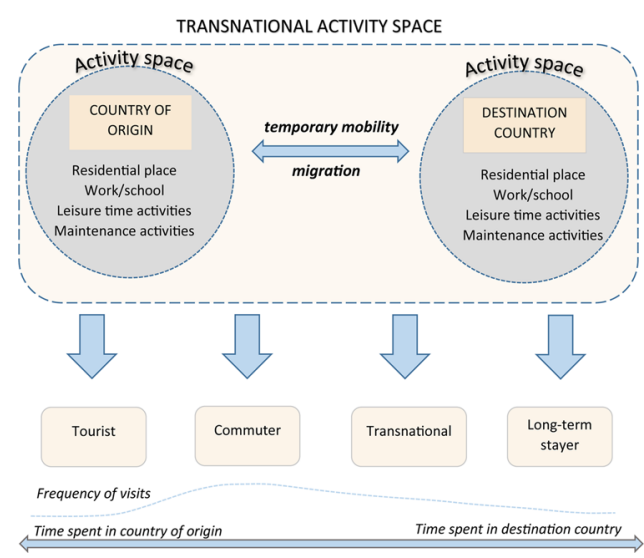

Fig. 2 Transnational activity space model that synthesises different connectivities between activity spaces located in distinct countries. The conceptual model is applied in current study: based on the frequency of visits and time spent in countries different visitor groups are defined (tourist, commuter, transnational, long-term stayer).

activities, permanent (migration) and temporary mobility beyond national borders (Fig. 2). At least three indicators are important for distinguishing different types of visitors and associated mobility patterns. First, trip motivation offers the most clear-cut explanation for the visit and is one of the most important variables in tourism statistics. However, this information is gathered mainly by conducting surveys or from accommodation establishments and it is difficult to link this with actual spatiotemporal mobility (Saluveer et al., 2020). Second, time spent in the country of origin and abroad can be another indicator for cross-border mobility. In fact, UNWTO (2010) states that for the case of highly mobile individuals, the territory with predominant presence in a given year is assigned as the country of residence. Third, frequency of visits can help to further distinguish frequent and regular (e.g., work commuters) and less frequent (e.g., transnationals) mobility.
In increasing order of length of time abroad, outbound visitors in this present study are divided into four groups based on the temporal dimension of their visits: tourists, commuters, transnationals, long-term stayers. Outbound visitors are categorised into visitor groups based on destination country, while the country of origin (i.e., SIM-card origin) is always Estonia. A person may belong to different visitor groups by destination country based on regularity and duration of visits. For example, the same person may be a commuter to Finland and a tourist in Greece. Since the data used in this study include time and location of call activities and do not include any information about trip motivation, visitors are divided into groups on the basis of three variables: frequency of visits to destination country, number of days spent in destination country, and number of days in country of origin (Estonia). These variables are calculated separately for each calendar year. Visitors are classified according to the following terms and order (Fig. 2):

1. Long-term stayers are those who stay abroad most of the time. We define these as people who spend $75 \%$ or more of their time in one destination country, and less than $25 \%$ of their time in Estonia. According to the UNWTO (2010) definition, their country of residence is very likely in the destination country.

2. Transnationals are people who are equally active in Estonia and in some other country and move regularly between their countries of origin and destination. We define these as people who spend at least 25\% of their days in Estonia and $25-75 \%$ of days in destination countries. They have to make a minimum of one visit to a country of destination in each of at least 6 of the 12 months of the calendar year. It might be difficult to distinguish the country of residence for this person because time spent abroad might be divided equally between many countries.

3. Commuters travel abroad on a regular basis but mainly reside in their country of origin. In this study, these are people who spend $<25 \%$ of their days in destination countries and at least 25\% of their days are spent in Estonia. They have to make a minimum of two visits to destination countries in each of at least 6 out of 12 months of the calendar year.

4. Tourists in this study are those who visit destination countries rarely and irregularly. They are defined as people who do not fall into any of the above groups and reside in their country of origin.

The share of Estonian speakers in our research population by visitor group is as follows: $91 \%$ tourists, $6 \%$ transnationals, $2 \%$ commuters, and $1 \%$ long-term stayers. The share of Russian speakers by visitor groups is as follows: $92 \%$ tourists, $4 \%$ transnationals, $3 \%$ commuters, and $1 \%$ long-term stayers.

Analysis methods. In order to analyse ethnic differences in crossborder mobility, we began by calculating mobility characteristics, which are used as dependent variables in the regression analysis: (1) number of trips in 2014-2016 (Model 1), (2) number of distinct countries visited in 2014-2016 (Model 2), (3) average duration of a trip (Model 3), (4) number of days spent abroad (Model 4). The main explanatory variable of interest is the language chosen for communication (Estonian or Russian), with other variables included like gender, year of birth, and the place of residence (Table 1). Separate models are provided for every dependent variable (Models 1-4). Because our dependent variables are overdispersed $\left(\mu \neq \sigma^{2}\right)$ and in the form of count data, we apply zero-truncated negative binomial regression analysis in Model 1 and Model 2, and negative binomial regression analysis 
Table 2 Descriptive figures (medians) of cross-border mobility by language group.

\begin{tabular}{lcc|} 
& $\begin{array}{c}\text { Estonian } \\
\text { speakers }\end{array}$ & $\begin{array}{l}\text { Russian } \\
\text { speakers }\end{array}$ \\
\hline Number of trips & 4 & 6 \\
Number of visited distinct & 3 & 3 \\
countries & & 4 \\
Average trip duration (days) & 3 & 20 \\
Number of days spent abroad & 15 & \\
\hline
\end{tabular}

in Model 3 and Model 4 (see Coxe et al., 2009; Huang and Cornell, 2012; Beaujean and Morgan, 2016). We tested overdispersion using the R package "AER" (Kleiber and Zeileis, 2020). The model formula for negative binomial and zero-truncated negative binomial regression is as follows:

$$
\ln (\mu)=\beta_{0}+\beta_{1} X_{1}+\beta_{2} X_{2}+\beta_{3} X_{3}+\beta_{4} X_{4}+\varepsilon_{i},
$$

where $\mu$ is the mean of the dependent variable $Y$ representing counts of trips, days spent abroad, average duration of trips, and number of visited countries. $\beta_{0}$ is intercept, $\beta_{n}$ is the regression coefficient for predictors, $X_{1}$ is communication language, $X_{2}$ is gender, $X_{3}$ is birth year category $X_{4}$ place of residence. The exponents of coefficients are equal to incident rate ratios (IRR). The IRR represents the change in the dependent variable (counts) in terms of a percentage increase or decrease.

Secondly, a binary logistic regression model is used to analyse the effect of independent variables on the odds of belonging to specific visitor groups. Separate models were created for every visitor group. The dependent variable has values $1-$ belonging to a certain visitor group, 0 -does not belong to a specific visitor group. It is important to note that a person could belong to several visitor groups. Because separate models were calculated for every visitor group (Model 5-8), each person is counted once in each model, i.e., there are no recurring observations in the models. The model formula for logistic regression is as follows:

$$
\log \left(\frac{p}{1-p}\right)=\beta_{0}+\beta_{1} X_{1}+\beta_{2} X_{2}+\beta_{3} X_{3}+\beta_{4} X_{4}+\varepsilon_{i},
$$

where the response variable $Y$ has a Bernoulli distribution with mean $p$. Thus $\left(\frac{p}{1-p}\right)$ represents the odds of belonging to a visitor group (tourist, commuter, transnational, long-term stayer). $\beta_{0}$ is the intercept, $\beta_{n}$ is the regression coefficient for particular predictors, $X_{1}$ is the communication language, $X_{2}$ is gender, $X_{3}$ is birth year category, and $X_{4}$ place of residence. The exponents of the coefficients are equal to the odds ratios (OR).

\section{Results}

Ethno-linguistic differences in transnational activity space. The results of this study indicate that there are ethno-linguistic differences in cross-border mobility for those who made at least one outbound trip during the study period (2014-2016). The travel intensity of the Russian-speaking minority is higher when compared with the Estonian-speaking majority population (Table 2): Estonian-speakers made on average four trips and Russianspeakers six trips during the study period. When the effect of other variables in the model is taken into account, the Russianspeaking minority makes $10 \%$ more trips abroad $(p<0.001$, Table 3 Model 1). Russian speakers' average duration of a trip is also longer-4 days for Russian speakers and 3 days for Estonian speakers (Table 2). When the effect of other variables is accounted for, their trip length is $14 \%$ longer $(p<0.001$, Table 3 Model 3), and they stay $17 \%$ more days abroad than Estonian speakers $(p<0.001$, Table 3 Model 4$)$. Russian speakers spent on average 20 days abroad and Estonian speakers 15 days. However, Russian speakers visit fewer countries than Estonian speakers (Table 3 Model 2).

In addition to language, gender and age are significantly $(p<$ 0.05 ) related to cross-border mobility (Table 3 ). Women make fewer trips than men, their trips are shorter, and they spend on average much less time abroad. However, there are no gender differences in the number of countries visited. The biggest age differences are between the youngest and the oldest age groups (Table 3). When looking at the characteristics of cross-border mobility across language and age groups (Fig. 3), then the median number of trips of Russian speakers is larger than that of the Estonian speakers across all age groups. The same pattern applies to the number of days spent abroad.

Place of residence also influences cross-border mobility and this is especially evident for the region where the Russianspeaking minority forms a regional majority-East-Estonia. EastEstonia is an industrial region that borders Russia and its inhabitants have the lowest average income in Estonia (Statistics Estonia, 2020). Indicators that describe cross-border mobility also illustrate the region's marginal position: when holding other variables constant, people living in East Estonia make fewer trips, their trips are shorter, they visit fewer countries, and they spent fewer days abroad compared to people living in other regions in Estonia.

Considering countries visited by ethno-linguistic and age groups, some clear trends are seen. Estonian speakers' top three visited countries are Latvia (visited by $59 \%$ of our research population), Finland (59\%), and Sweden (33\%). Older Estonian speakers visit predominantly Latvia, while younger people visit predominantly Finland. Russian speakers' top three destination countries are Russia (65\%), Latvia (49\%), and Finland (37\%). Interestingly, the sequence of the countries is the same across all age groups: Russia is clearly one of the most important travel destinations for Russian speakers in all age groups. However, the proportion of Russian speakers who have visited Finland is greater in younger age groups. This shows that younger age groups prone to higher mobility are increasingly creating more ties with Finland, while at the same time keeping close connections with Russia. Thus, we find a continued attachment to the country of ancestry in subsequent migrant generations among Russian-speakers.

Ethnic differences in belonging to visitor groups and their destination countries. Ethno-linguistic background plays a significant $(p<0.05)$ role in explaining the membership of different visitor groups, namely for tourist and commuter groups (Table 3 Model 5, Model 6). Russian speakers have a $20 \%$ increase in the odds of belonging to the commuters group than Estonian speakers $(p<0.05)$ and an $88 \%$ increase in the odds of being tourists compared to Estonian speakers $(p<0.001)$. In addition to language, women have smaller chances of being a commuter than men but higher odds of being a tourist. Surprisingly, no major age differences occur in either commuter or tourist groups.

People living in West Estonia have a higher probability of belonging to all visitor groups apart from tourists compared to people living in East Estonia. One of the most important routes that connects Baltic states to Europe (Via Baltica E67) runs through West Estonia and enhances cross-border mobility. Despite living close to their country of ancestry, people living in East Estonia have to pass the border-crossing point with Russia, which does not belong to the Schengen Area (Visa Free Zone) and thus complicates travel to Russia. Like people living in West Estonia, people living in Central and South Estonia also have an elevated probability of belonging to the transnational and 


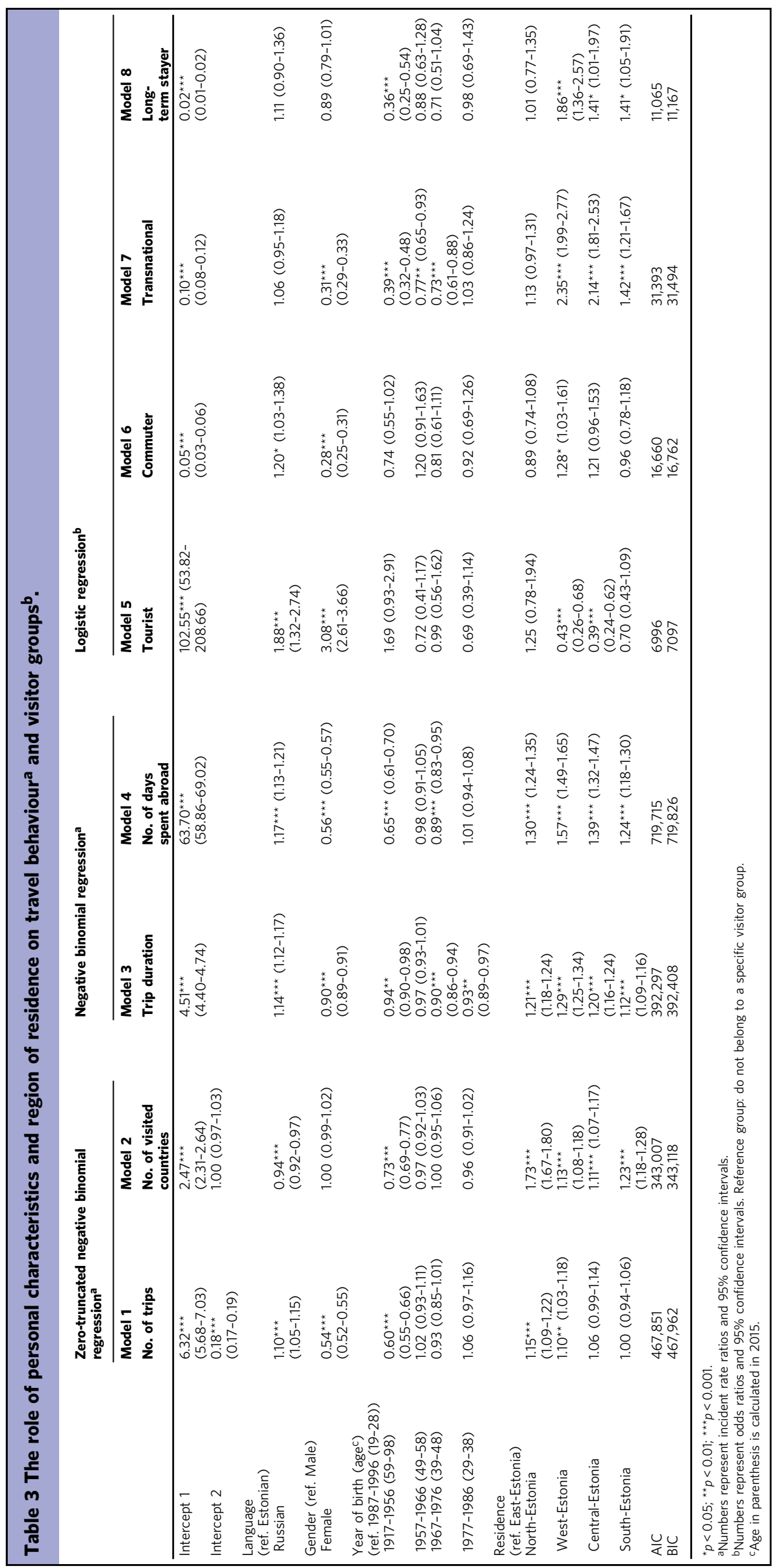



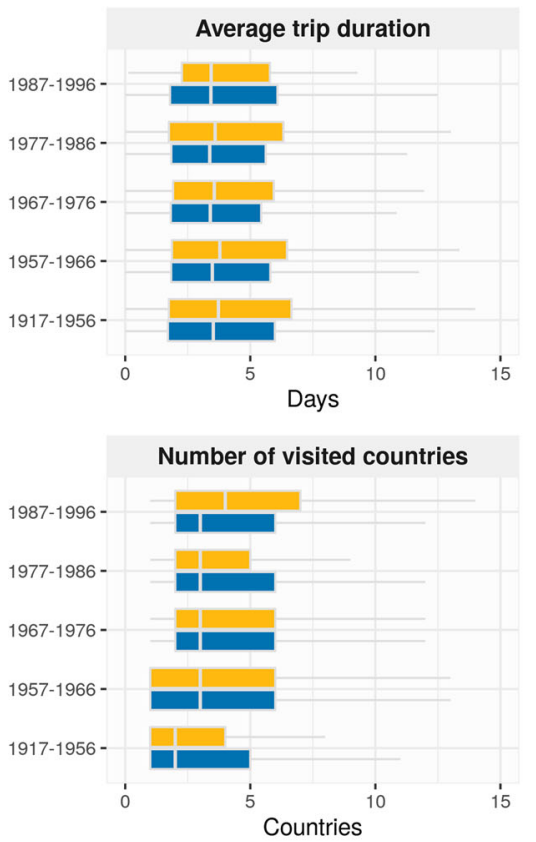

Estonian
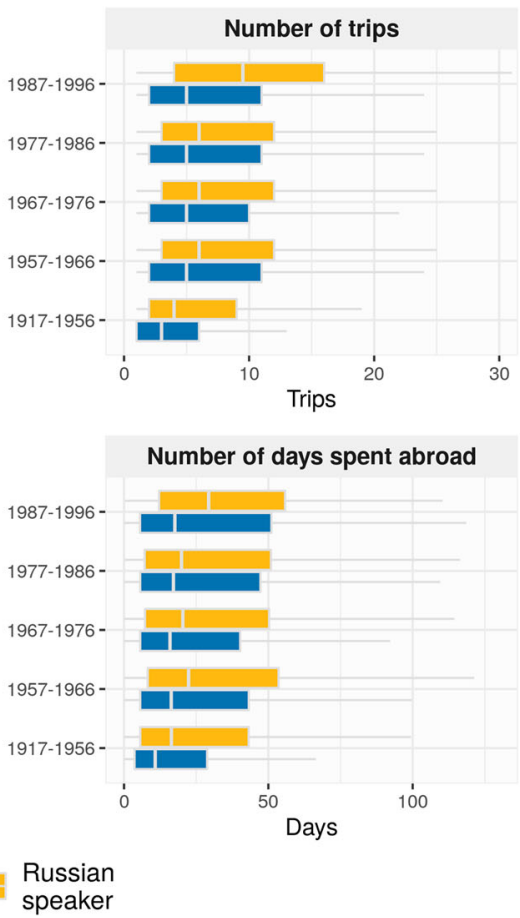

Fig. 3 Cross-border mobility characteristics of Estonian speakers and Russian speakers across age groups. Box and whisker plots of dependent variables (number of trips, average duration of trip, number of visited countries, number of days spent abroad) of Russian speakers and Estonian speakers across age groups.

long-term stayer groups. These are the regions with the biggest problems in finding a job, and working abroad most likely characterises these two groups.

Main destination regions are similar for commuters and tourists (Finland, Baltic states, North-European countries), and for transnationals and long-term stayers (Finland, NorthEuropean, West-European countries). When looking at the countries visited across visitor and ethno-linguistic groups, no differences occur in the group most related to working abroadlong-term stayers. The top three destination countries both for Estonian and Russian speakers are the high-income Nordic countries of Finland, Sweden, and Norway. Similarly, both Estonian-speaking and Russian-speaking transnationals are bound with Finland (65\% and 33\%, respectively), followed by Sweden $(8 \%)$ and Norway (8\%) for Estonian speakers, and Russia (24\%) and Sweden (13\%) for Russian speakers. The main destination country for Estonian-speaking commuters is again Finland (44\%) but for Russian-speaking commuters the most important destination is Russia (40\%) (Fig. 4a, b). Ethnolinguistic differences in the top tourism destinations are the strongest, with Estonian-speakers' number one destination being Latvia (61\%) and for Russian-speakers Russia (65\%). The Mediterranean region as a popular tourism destination applies to both language groups, however, Italy is visited by more Estonian speakers than Russian speakers (Fig. 4c, d).

\section{Discussion and conclusions}

In this paper, we have focused on the intersection of ethnolinguistic background and mobility within the transnational activity space framework using mobile phone Call Detail Records data that allow the study of mobility that crosses nation-state borders. Activity-space studies mainly focus on activities and daily travel within one country. However, activities nowadays often stretch beyond national borders and this may take place for different reasons for members of different ethno-linguistic groups.

The first important conclusion of this study is that the crossborder mobility of the Russian-speaking minority in Estonia is more intense: Russian-speakers travel abroad more often than Estonian speakers, their trips last longer, and overall they spend more time abroad. This finding is somewhat similar to the study of Feng and Page (2000), who found that the propensity to travel is higher for the Chinese ethnic minority than for the majority population in New Zealand. This counters the expectation that frequent travelling relates to bigger economic resources and being occupied with high-end jobs (Delhey et al., 2015) since the Russian-speaking population in Estonia has lower average incomes than the Estonian-speaking majority population (Statistics Estonia, 2020).

Hence, income alone might not be the most important predictor of cross-border mobility, indicating the existence of alternative explanations and to the potential interlinkages between different causes such as economic resources, social networks, as well as preferences. The study by Benz (2019) in Gojal region Pakistan shows how mobility is part of the household livelihood strategies where social networks play a key role. According to Larsen et al. (2006), going to the country of ancestry allows for budget travel with low costs for accommodation and meals. Secondly, moving abroad may contribute to an exit from a marginal position if it is related to working abroad. When a person does not find a suitable job in the home country, this could lead to work-related commuting between countries (Telve, 2016).

Our second main conclusion shows that members of the Russian-speaking minority are more likely to belong to the tourist and commuter groups. We further find that belonging to those two groups is more common among men as well as in those regions of Estonia where the ethno-linguistic minority (Russianspeakers) forms a regional majority. It may also be that buying 

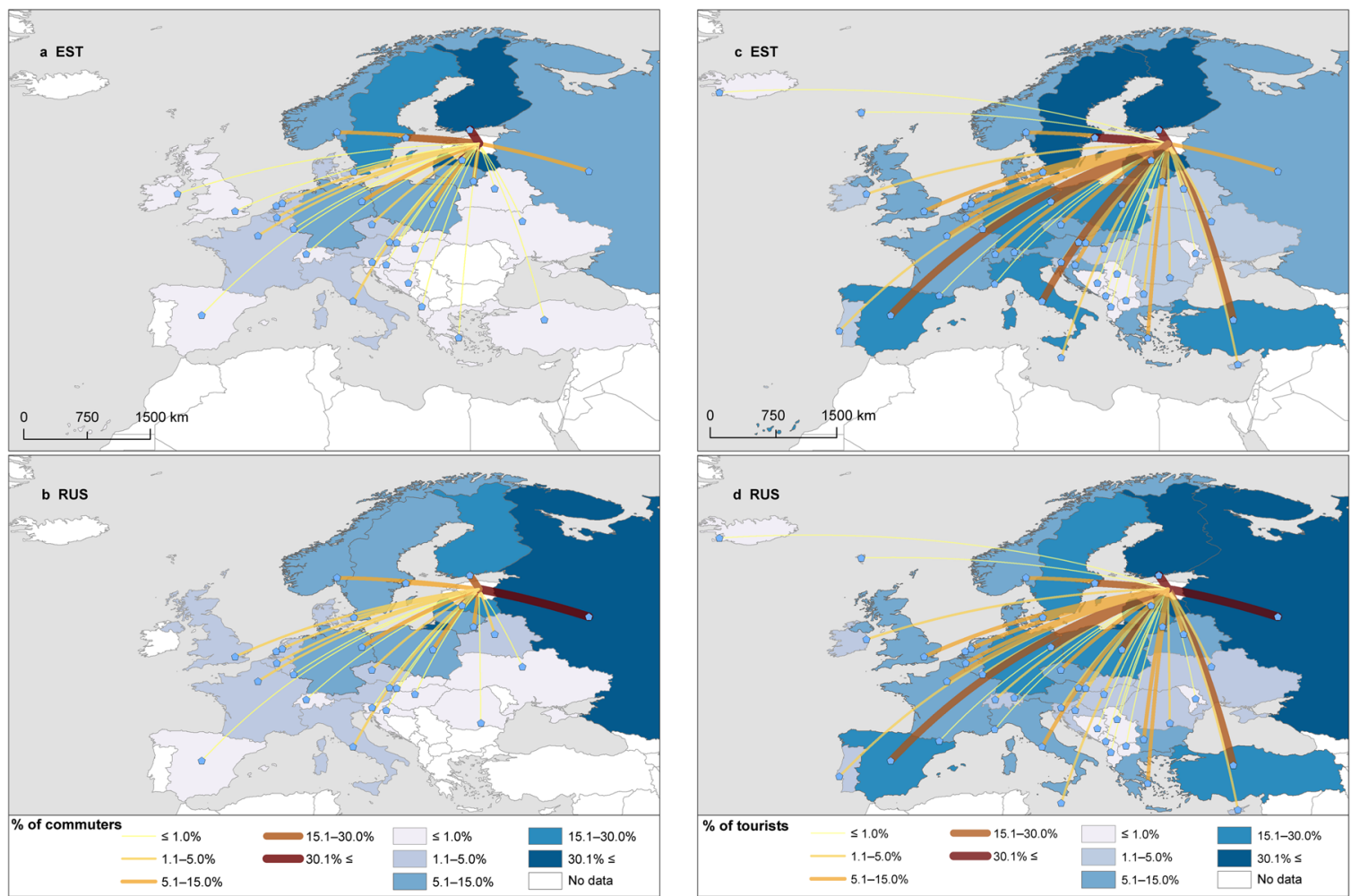

Fig. 4 Visits to destination countries by proportions of Estonian-speaking and Russian-speaking commuters and tourists. Percentages and flow lines indicate the share of Estonian-speaking commuters $\mathbf{a}$, Russian-speaking commuters $\mathbf{b}$, Estonian-speaking tourists $\mathbf{c}$, Russian-speaking tourists $\mathbf{d}$ that have visited different countries on the European continent (incl. Turkey).

cheaper goods and services abroad can be an incentive for frequent or irregular and short-term travel abroad. Since the price level for goods and services in neighbouring countries of Russia and Latvia is lower compared to Estonia, this may explain the short and irregular trips of Russian-speakers living in EastEstonia abroad, especially to Russia. Such cross-border commuting may even be a way of making a livelihood for some people living close to the border. People living in Central and South Estonia who are economically less successful are more likely to belong to visitor groups that stay abroad longer (transnational and long-term stayer) and are most likely to work abroad.

Our third main conclusion is that the ethno-linguistic minority visits fewer countries and travels often to the country of ancestry. Most importantly, there are no age differences in top destination countries for the Russian-speaking minority, showing that the attraction of the country of ancestry remains high even for the third generation of migrants. Verdery et al. (2018) claim that transnational ties remain relatively strong for many generations. Our results also show that trips to the country of ancestry remain frequent across many migrant generations. Preference to travel to the country of ancestors can be related to a country's pull-effect, with often mixed sets of reasons such as wishing to search for one's roots (Duval, 2003; Hughes and Allen, 2010), to visit relatives and friends (Griffin, 2017), to do business or take a holiday (Seetaram, 2012; Dwyer et al., 2014), or it can be a learned behaviour from family (McKercher and Yankholmes, 2018; Klemm, 2002).

This study has extended the analysis of ethno-linguistic differences in mobility into a transnational activity space. The rising tide of segregation research stresses the importance of observing the full spectrum of activities in order to understand the functioning of ethnic communities. Trips to the country of ancestry help to maintain ethnic identity and social ties (Duval, 2003;
Li and McKercher, 2016; Verdery et al., 2018; Hung et al., 2013). Thus, the success and status of minorities today does not solely depend on integration into the host society as assumed in classical assimilation theories. In addition, the role of strong ties across national borders might open up new possibilities for self-realisation, cultural maintenance, and economic success for minorities (Portes et al., 1999). Thus, it is important to consider crossborder temporary mobility such as job-related commuting and holiday travelling to better understand the functioning of ethnolinguistic communities and the effect of such mobility on the persistence of segregation. According to the emerging activity space-based approach to segregation, different parts of the activity space are interrelated and inequalities can be transferred from one activity site to another (van Ham et al., 2018). However, our study shows that the transnationalization of the activity space may also help to break such vicious circles of segregation, and create exit points for the individual from marginal positions, at least in economic terms.

Drawing from the mobility justice framework, the (in)equalities related to ethno-linguistic background and mobility may not only be transferred from one activity site to another as discussed in activity space segregation research, but also from one country to another. Since segregation is foremost a geographical phenomenon, it also needs to be analysed from different angles and beyond single-country borders. It can be argued that mobility in general and cross-border mobility in particular may deepen existing social disparities, create new social disparities, as well as helping to exit from social disparities. Hence, high levels of segregation in the destination country can be the result of people's strategy for exiting low-income neighbourhoods in the country of origin.

Many new and important questions stem from the transnational activity space-based approach to segregation. For example, 
is social advantage or disadvantage transferred through crossborder mobility to receiving countries? What happens to those who are immobile-do the social disparities in the host country deepen? The issue of shifting inequalities between countries becomes evident in Sheller (2019) and Cass and Manderscheid (2019), who state that while better mobility options have been seen as a key enabler for better access to opportunity structures for marginalised groups, inequalities are shifted to regions that suffer the most from the environmental and socio-economic consequences of increasing global mobility.

To conclude, new data sources such as mobile phone data used in this study increase the research opportunities in mobility and segregation since many aspects of the mobility remain hidden to traditional data sources such as censuses and registers. New data sources would allow for more detailed investigation on the transmission of segregation and spatial inequalities across borders. However, such new data is not without its own limitations. For example, mobile phone data misses information on the trip motivation and economic resources of people. Since many people use data abroad instead of making call activities, having roaming data that would also include data usage information would enhance the precision of analysing cross-border mobility. Nevertheless, the data used in this study opens new and interesting avenues to observing different visitor groups with different ethno-linguistic backgrounds and cross-border mobility. In addition, the high temporal precision of the mobile phone dataset enables us to track changes in cross-border mobility over a long time period. The availability of data on intra-destination mobility from several countries and mobile network operators would enable more precise research on visitors' transnational activity space and its effect on segregation both in countries of origin and destination. Also, the inclusion of people who are immobile in terms of cross-border mobility to the analysis is crucial. These all contribute to the better understanding on how inequalities are produced and reproduced in the modern world where part of the life of many people takes place in many countries.

\section{Data availability}

The passive mobile positioning data analysed during the current study are not publicly available since this would compromise the data agreement with the mobile network operator that provided these data.

Received: 10 April 2020; Accepted: 8 October 2020; Published online: 04 November 2020

\section{References}

Ahas R, Silm S, Järv O, Saluveer E, Tiru M (2010) Using mobile positioning data to model locations meaningful to users of mobile phones. J Urban Technol 17 (1):3-27. https://doi.org/10.1080/10630731003597306

Ahas R, Silm S, Tiru M (2017) Tracking trans-nationalism with mobile telephone data. In: Tammaru T, Eamets R, Kallas K (ed.) Estonian human development report 2016/2017: Estonia at the age of migration. https://inimareng.ee/en/. Accessed Jan 2020

Ali N, Holden A (2006) Post-colonial Pakistani mobilities: the embodiment of the 'myth of return' in tourism. Mobilities 1(2):217-242. https://doi.org/10.1080/ 17450100600726605

Allen JP, Turner E (2012) Black-white and hispanic-white segregation in U.S. counties. Prof Geogr 64(4):503-520. https://doi.org/10.1080/ 00330124.2011 .611426

Anniste K, Tammaru T (2014) Ethnic differences in integration levels and return migration intentions: a study of Estonian migrants in Finland. Demogr Res 30(1):377-412

Beaujean AA, Morgan GB (2016) Tutorial on using regression models with count outcomes using R. Pract Assess Res Eval 21. https://doi.org/10.7275/pj8ch254
Benz A (2019) Mobility (in)justice, positionality and translocal development in Gojal, Pakistan. In: Cook N, Butz D (eds) Mobilities, mobility justice and social justice. Routledge, London and New York, pp. 201-214

Bolognani M (2014) Visits to the country of origin: how second-generation British Pakistanis shape transnational identity and maintain power asymmetries. Glob Netw 14(1):103-120. https://doi.org/10.1111/glob.12015

Brubaker R (2011) Nationalizing states revisited: projects and processes of nationalization in post-Soviet states. Ethn Racial Stud 24(11):1785-1814. https:// doi.org/10.1080/01419870.2011.579137

Cachia R, Jariego IM (2018) Mobility types, transnational ties and personal networks in four highly skilled immigrant communities in Seville (Spain). Soc Netw 53:111-124. https://doi.org/10.1016/j.socnet.2017.03.014

Cass N, Manderscheid K (2019) The autonombility system. Mobility justice and freedom under sustainability. In: Cook N, Butz D (eds) Mobilities, mobility justice and social justice. Routledge, London and New York, pp. $101-115$

Cook N, Butz D (eds) (2019) Mobilities, mobility justice and social justice. Routledge, London and New York

Coxe S, West SG, Aiken LS (2009) The analysis of count data: a gentle introduction to poisson regression and its alternatives. J Pers Assess 91(2):121-136. https:// doi.org/10.1080/00223890802634175

Cresswell T (2011) Mobilities I: catching up. Prog Hum Geogr 35(4):550-558. https://doi.org/10.1177/0309132510383348

Delhey J, Deutschmann E, Cirlanaru K (2015) Between 'class project' and individualization: the stratification of Europeans' transnational activities. Int Sociol 30(3):269-293. https://doi.org/10.1177/0268580915578744

Deutschmann E (2016) The spatial structure of transnational human activity. Soc Sci Res 59:120-136. https://doi.org/10.1016/j.ssresearch.2016.04.008

Duval DT (2003) When hosts become guests: return visits and diasporic identities in a commonwealth Eastern Caribbean community. Curr Issues Tour 6 (4):267-308. https://doi.org/10.1080/13683500308667957

Dwyer L, Seetaram N, Forsyth P, King B (2014) Is the migration-tourism relationship only about VFR? Ann Tour Res 46:130-143. https://doi.org/10.1016/ j.annals.2014.03.009

Ehrkamp P (2005) Placing identities: transnational practices and local attachments of Turkish immigrants in Germany. J Ethn Migr Stud 31(2):345-364. https:// doi.org/10.1080/1369183042000339963

Estonian Consumer Protection and Technical Regulatory Authority (2019) Survey on mobile internet data communication speeds in Estonia

Estonian Land Board (2011) https://geoportaal.maaamet.ee/eng/Spatial-Data-p58. html

European Parliament and Council of the European Union (2016) General data protection regulation. https://eur-lex.europa.eu/eli/reg/2016/679/oj Accessed Sept 2019

Eurobarometer (2014) Special Eurobarometer 414 E-Communications and telecom single market: household survey. European Union

Feng K, Page SJ (2000) An explanatory study of the tourism, migration-immigration nexus: travel experiences of Chinese residents in New Zealand. Curr Issues Tour 3(3):246-281. https://doi.org/10.1080/ 13683500008667875

Floyd D (1999) Race, ethnicity and use of the national park system. Soc Sci Res Rev $1(2): 1-24$

Golledge RG, Stimson RJ (1997) Spatial behavior: a geographic perspective. Guilford Press, New York

Griffin T (2017) Immigrant hosts and intra-regional travel. Tour Geogr 19 (1):44-62. https://doi.org/10.1080/14616688.2016.1169314

Hall M, Iceland J, Yi Y (2019) Racial separation at home and work: segregation in residential and workplace settings. Popul Res Policy Rev 38(5):671-694. https://doi.org/10.1007/s11113-019-09510-9

van Ham M, Tammaru T, Jannsen HJ (2018) A multi-level model of vicious circles of socio-economic segregation. In: OECD Divided cities: Understanding intra-urban disparities. OECD Publishing, Paris. https://doi.org/10.1787/ 9789264300385-8-en

van Ham M, Tammaru T (2011) Ethnic minority-majority unions in Estonia. Eur J Popul 27:313-335. https://doi.org/10.1007/s10680-011-9236-z

van Ham M, Tammaru T (2016) New perspectives on ethnic segregation over time and space. A domains approach. Urban Geogr 37(7):953-962. https://doi.org/ 10.1080/02723638.2016.1142152

Hannonen O, Tuulentie S, Pitkänen K (2015) Borders and second home tourism: Norwegian and Russian second home owners in Finnish border areas. J Borderl Stud 30(1):53-67. https://doi.org/10.1080/08865655.2015. 1012736

Huang FL, Cornell DG (2012) Pick your Poisson: a tutorial on analyzing counts of student victimization data. J Sch Violence 11(3):187-206. https://doi.org/ $10.1080 / 15388220.2012 .682010$

Huang WJ, Ramshaw G, Norman WC (2016) Homecoming or tourism? Diaspora tourism experience of second-generation immigrants. Tour Geogr 18 (1):59-79. https://doi.org/10.1080/14616688.2015.1116597 
Hughes H, Allen D (2010) Holidays of the Irish diaspora: the pull of the 'homeland'? Curr Issues Tour 13(1):1-19. https://doi.org/10.1080/ 13683500802495669

Humbracht M (2015) Reimagining transnational relations: the embodied politics of visiting friends and relative mobilities. Popul Space Place 21(7):640-653. https://doi.org/10.1002/psp.1918

Hung K, Xiao H, Yang X (2013) Why immigrants travel to their home places: social capital and acculturation perspective. Tour Manag 36:304-313. https://doi. org/10.1016/j.tourman.2012.12.010

International Organization for Migration (2019) World migration report 2020. https://publications.iom.int/books/world-migration-report-2020. Accessed Mar 2020

Järv O, Ahas R, Witlox F (2014) Understanding monthly variability in human activity spaces: a twelve-month study using mobile phone call detail records. Transp Res Part C 38:122-135. https://doi.org/10.1016/j.trc.2013.11.003

Järv O, Müürisepp K, Ahas R, Derudder B, Witlox F (2015) Ethnic differences in activity spaces as a characteristic of segregation: a study based on mobile phone usage in Tallinn, Estonia. Urban Stud 52(14):2680-2698. https://doi. org/10.1177/0042098014550459

Järv O, Masso A, Silm S, Ahas R (2020) The link between ethnic segregation and socio-economic status: an activity space approach. Tijds voor econ en Soc Geog. https://doi.org/10.1111/tesg.12465

Kamenjuk P, Aasa A, Sellin J (2017) Mapping changes of residence with passive mobile positioning data: the case of Estonia. Int J Geogr Inf Sci 31 (7):1425-1447. https://doi.org/10.1080/13658816.2017.1295308

van Kempen R, Özüekren AŞ (1998) Ethnic segregation in cities: new forms and explanations in a dynamic world. Urban Stud 35(10):1631-1656. https://doi. org/10.1080/0042098984088

Kılıç ÖO, Akyol MA, Işık O, Kılıç BG, Aydınoğlu AU, Surer E, Düzgün HŞ, Kalaycıoğlu S, Taşkaya-Temizel T (2019) The use of big mobile data to gain multilayered insights for Syrian refugee crisis. In: Salah A, Pentland A, Lepri $B$, Letouzé E (ed) Guide to mobile data analytics in refugee scenarios. Springer, Cham

Kleiber C, Zeileis A (2020) AER: applied econometrics with R. https://cran.rproject.org/web/packages/AER/index.html. Accessed Mar 2018

Klemm MS (2002) Tourism and ethnic minorities in Bradford: the invisible segment. J Travel Res 41(1):85-91. https://doi.org/10.1177/004728750204100112

Korts K (2009) Inter-ethnic attitudes and contacts between ethnic groups in Estonia. J Balt Stud 40(1):121-137. https://doi.org/10.1080/ 01629770902722286

Krysan M, Crowder K (2017) Cycle of segregation: social processes and residential stratification. Russell Sage Foundation, New York

Kukk K, van Ham M, Tammaru T (2019) EthniCity of leisure: a domains approach to ethnic integration during free time activities. Tijdschr Econ Soc Geogr 110 (3):289-302. https://doi.org/10.1111/tesg.12307

Kwan MP (2013) Beyond space (as we knew it): toward temporally integrated geographies of segregation, health, and accessibility: space-time integration in geography and GIScience. Ann Assoc Am Geogr 103(5):1078-1086. https:// doi.org/10.1080/00045608.2013.792177

Lai S, zu Erbach-Schoenberg E, Pezzulo C, Ruktanonchai NW, Sorichetta A, Steele J, Li T, Dooley CA, Tatem AJ (2019) Exploring the use of mobile phone data for national migration statistics. Palgrave Commun 5:34. https://doi.org/ 10.1057/s41599-019-0242-9

Larsen J, Axhausen KW, Urry J (2006) Geographies of social networks: meetings, travel and communications. Mobilities 1(2):261-283. https://doi.org/10.1080/ 17450100600726654

Leetmaa K (2017) Place of residence as a measure of integration: changes in ethnolinguistic residential segregation. In: Tammaru T, Eamets R, Kallas K (eds.) Estonian human development report 2016/2017: Estonia at the age of migration. https://inimareng.ee/en/. Accessed Jan 2020

Li TE, McKercher B (2016) Developing a typology of diaspora tourists: return travel by Chinese immigrants in North America. Tour Manag 56:106-113. https://doi.org/10.1016/j.tourman.2016.04.001

Masso A, Silm S, Ahas R (2019) Generational differences in spatial mobility: a study with mobile phone data. Popul Space Place 25(2):e2210. https://doi.org/ $10.1002 /$ psp. 2210

McKercher B, Yankholmes A (2018) Travel as learned behaviour: Western migrants in Hong Kong and Macau. Tour Manag 67:191-200. https://doi.org/ 10.1016/j.tourman.2018.01.006

Mooses V, Silm S, Ahas R (2016) Ethnic segregation during public and national holidays: a study using mobile phone data. Geogr Ann Ser B 98(3):205-219. https://doi.org/10.1111/geob.12100

Mägi K, Leetma K, Tammaru T, van Ham M (2016) Types of spatial mobility and change in people's ethnic residential contexts. Demogr Res 34 (1):1161-1192

Mägi K, van Ham M, Leetma K, Tammaru T (2020) The neighbourhood context and changes in self-reported ethnic identity. J Eth Migr Stud 46(1):277-296. https://doi.org/10.1080/1369183X.2018.1547634
O'Connor PM (2010) Bodies in and out of place: embodied transnationalism among invisible immigrants - the contemporary Irish in Australia. Popul Space Place 16:75-83. https://doi.org/10.1002/psp.577

Patacchini E, Zenou Y (2012) Ethnic networks and employment outcomes. Reg Sci Urban Econ 42(6):938-949. https://doi.org/10.1016/j.regsciurbeco.2012.01.004

Peters K, de Haan H (2011) Everyday spaces of inter-ethnic interaction: the meaning of urban public spaces in the Netherlands. Leis Loisir 35 (2):169-190. https://doi.org/10.1080/14927713.2011.567065

Portes A, Guarnizo LE, Landolt P (1999) The study of transnationalism: pitfalls and promise of an emergent research field. Ethn Racial Stud 22(2):217-237. https://doi.org/10.1080/014198799329468

Põder K, Lauri T, Rahnu L (2017) Challenges facing the Estonian school system: the achievement gap between language-stream schools and school choice by immigrants. In: Tammaru T, Eamets R, Kallas K (eds) Estonian human development report 2016/2017: Estonia at the age of migration. https:// inimareng.ee/en/. Accessed Jan 2020

Raun J, Ahas R, Tiru M (2016) Measuring tourism destinations using mobile tracking data. Tour Manag 57:202-212. https://doi.org/10.1016/j. tourman.2016.06.006

Saar E, Helemäe J (2017) Ethnic segregation in the Estonian labour market. In: Tammaru T, Eamets R, Kallas K (eds) Estonian human development report 2016/2017: Estonia at the age of migration. https://inimareng.ee/en/. Accessed Jan 2020

Saluveer E, Raun J, Tiru M, Altin L, Kroon J, Snitsarenko T, Aasa A, Silm S (2020) Methodological framework for producing national tourism statistics from mobile positioning data. Ann Tour Res 81:102895. https://doi.org/10.1016/j. annals.2020.102895

Seetaram N (2012) Immigration and international inbound tourism: empirical evidence from Australia. Tour Manag 33(6):1535-1543. https://doi.org/ 10.1016/j.tourman.2012.02.010

Sheller M, Urry J (2006) The new mobilities paradigm. Environ Plan A 38 (2):207-226. https://doi.org/10.1068/a37268

Sheller M (2019) Theorizing mobility justice. In: Cook N, Butz D (eds) Mobilities, mobility justice and social justice. Routledge, London and New York, pp. $22-36$

Shen Y (2019) Segregation through space: a scope of the flow-based spatial interaction model. J Transp Geogr 76:10-23. https://doi.org/10.1016/j. jtrangeo.2019.02.007

Silm S, Ahas R, Mooses V (2018) Are younger age groups less segregated? Measuring ethnic segregation in activity spaces using mobile phone data. J Ethn Migr Stud 44(11):1797-1817. https://doi.org/10.1080/1369183X.2017.1400425

Silm S, Ahas R (2014) Ethnic differences in activity spaces: a study of out-of-home nonemployment activities with mobile phone data. Ann Assoc Am Geogr 104 (3):542-559. https://doi.org/10.1080/00045608.2014.892362

Silm S, Järv O, Masso A (2020) Tracing human mobilities through mobile phones. In: Büschner M, Freudendal-Pedersen M, Kesselring S, Grauslund Kristensen $\mathrm{N}$ (eds) Handbook of Research Methods and Applications for Mobilities. Edward Elgar Publishing, Cheltenham, pp. 182-192

Silm S, Jauhiainen JS, Raun J, Tiru M (2020) Temporary population mobilities between Estonia and Finland based on mobile phone data and the emergence of a cross-border region. Eur Plan Stud. https://doi.org/10.1080/ 09654313.2020.1774514

Statistics Estonia (2011) Population and housing census 2011. https://www.stat.ee/en. Accessed Sept 2019

Statistics Estonia (2016) Citizenship of Estonian population. https://www.stat.ee/en. Accessed Sept 2019

Statistics Estonia (2020) Average monthly gross income per employee and recipients of gross income by region/administrative unit, sex and age group. Equalised yearly disposable income by ethnic nationality and sex https:// www.stat.ee/en. Accessed Sept 2020

Statistics Estonia (2015). https://vana.stat.ee/296050. Accessed Dec 2018

Strömgren M, Tammaru T, Danzer AM, van Ham M, Marcińczak S, Stjernström O, Lindgren U (2014) Factors shaping workplace segregation between natives and immigrants. Demography 51(2):645-671. https://doi.org/10.1007/ s13524-013-0271-8

Zorlu A, Mulder CH (2010) Location choices of migrant nest-leavers: spatial assimilation or continued segregation? Adv Life Course Res 15(2-3):109-120. https://doi.org/10.1016/j.alcr.2010.06.001

Tammaru T, Kulu H (2003) The ethnic minorities of Estonia: changing size, location, and composition. Eurasian Geogr Econ 44(2):105-120. https://doi org/10.2747/1538-7216.44.2.105

Telve K (2016) Cross-border commuting changes the way work is done: a case study of Estonian blue-collar and skilled workers in Finland. Ethnol Fenn 43:28-42

Toomet O, Silm S, Saluveer E, Ahas R, Tammaru T (2015) Where do ethnolinguistic groups meet? How copresence during free-time is related to copresence at home and at work. PLoS ONE 10(5):e0126093. https://doi.org/ 10.1371/journal.pone.0126093 
Vacca R, Solano G, Lubbers MJ, Molina JL, McCarthy C (2018) A personal network approach to the study of immigrant structural assimilation and transnationalism. Soc Netw 53:72-89. https://doi.org/10.1016/j. socnet.2016.08.007

Verdery AM, Mouw T, Edelblute H, Chavez S (2018) Communication flows and the durability of a transnational social field. Soc Netw 53:57-71. https://doi. org/10.1016/j.socnet.2017.03.002

Verdier T, Zenou Y (2017) The role of social networks in cultural assimilation. J Urban Econ 97:15-39. https://doi.org/10.1016/j.jue.2016.11.004

Vihalemm T (1999) Group identity formation processes among Russian-speaking settlers of Estonia: a linguistic perspective. J Balt Stud 30(1):18-39. https:// doi.org/10.1080/01629779800000211

Waldinger R (2008) Between "here" and "there": immigrant cross-border activities and loyalties. Int Migr Rev 42(1):3-29. https://doi.org/10.1111/j.17477379.2007.00112.x

Wang D, Li F, Chai Y (2012) Activity spaces and sociospatial segregation in Beijing. Urban Geogr 33(2):256-277. https://doi.org/10.2747/02723638.33.2.256

Wang D, Li F (2016) Daily activity space and exposure: a comparative study of Hong Kong's public and private housing residents' segregation in daily life. Cities 59:148-155. https://doi.org/10.1016/j.cities.2015.09.010

Williams KH, Chacko HE (2008) The effect of ethnic differences on travel characteristics: an exploration of marginality and ethnicity in urban tourism. Int J Hosp Tour Adm 9(2):147-163. https://doi.org/10.1080/ 15256480801907893

Wissink B, Schwanen T, van Kempen R (2016) Beyond residential segregation: introduction. Cities 59:126-130. https://doi.org/10.1016/j.cities.2016.08.010

Wong DWS, Shaw SL (2011) Measuring segregation: an activity space approach. J Geogr Syst 13(2):127-145. https://doi.org/10.1007/s10109-010-0112-x

Xu Y, Belyi A, Santi P, Ratti C (2019) Quantifying segregation in an integrated urban physical-social space. J R Soc Interface 16(160):20190536. https://doi. org/10.1098/rsif.2019.0536

Yip NM, Forrest R, Xian S (2016) Exploring segregation and mobilities: application of an activity tracking app on mobile phone. Cities 59:156-163. https://doi. org/10.1016/j.cities.2016.02.003

UNWTO (2020) World tourism barometer and statistical annex Jan 2020. https:// www.e-unwto.org/doi/pdf/10.18111/wtobarometereng.2020.18.1.1. Accessed Mar 2020

UNWTO (2010) International recommendations for tourism statistics 2008 series M no. 83/Rev.1. New York

\section{Acknowledgements}

The authors dedicate this article to the memory of Prof. Rein Ahas, who founded the Mobility Lab at the University of Tartu, in honour of his academic legacy in the field of mobile phone-based research in the broad field of social sciences. The authors would also like to thank the mobile network operators and Positium for providing mobile phone data, and the members of CCAMEU Jean Monnet Network for inspiring discussions on mobilities. This work was supported by the Estonian Research Council under Grant no. PUT PRG306, the Estonian Science Infrastructure Road Map project "Infotechnological Mobility Observatory (IMO)", project Rita-RÄNNE, and the University of Tartu ASTRA Project PER ASPERA.

\section{Competing interests}

The authors declare no competing interests.

\section{Additional information}

Correspondence and requests for materials should be addressed to V.M.

Reprints and permission information is available at http://www.nature.com/reprints

Publisher's note Springer Nature remains neutral with regard to jurisdictional claims in published maps and institutional affiliations.

\begin{abstract}
Open Access This article is licensed under a Creative Commons $\mathrm{BY}$
Attribution 4.0 International License, which permits use, sharing,
adaptation, distribution and reproduction in any medium or format, as long as you give appropriate credit to the original author(s) and the source, provide a link to the Creative Commons license, and indicate if changes were made. The images or other third party material in this article are included in the article's Creative Commons license, unless indicated otherwise in a credit line to the material. If material is not included in the article's Creative Commons license and your intended use is not permitted by statutory regulation or exceeds the permitted use, you will need to obtain permission directly from the copyright holder. To view a copy of this license, visit http://creativecommons.org/ licenses/by/4.0/.
\end{abstract}

(C) The Author(s) 2020 